\title{
Francuskie towarzystwa i czasopisma bibliofilskie w latach 1820-1939
}

W

1789 r. w ręlkach bibliofilów francuskich znajdowało się około 13 milionów książek, a kolekcjonerzy tego okresu poczęli interesować się nie tylko książką starą, rzadką i zabytkową, lecz również współczesną książką ilustrowaną ${ }^{1}$. Zbiory te, bęlące głównie w ręlkach arystokracji, w wyniku rewolucji uległy rozbiciu i znacznemu rozproszeniu, trafiając na wtórny rynek księgarski, a stąd w ręce bogatego mieszczaństwa, a niekiedy tė̇ i spekulantów. Ogromne ilości cennych książelk sprzedawane były czasem za bezcen u nadsekwańskich bukinistów. „Pierwsza połowa XIX wieku to złoty okres ulicznego handlu książką..." pisze Svend Dahl w swej pracy Dzieje ksiązki ${ }^{2}$. Nowi właściciele częstokroć nie mieli pojęcia o historycznej, a nawet materialnej wartości posiadlanych książek i clopiero pojawienie się w początkach XIX w. ${ }^{3}$ szeregu bibliografii bibliofilskich w opracowaniu Ch. Duclosa, G. Peignota czy J. Ch. Bruneta spowodowało bardziej świadome i planowane tworzenie lub uzupełnianie kolekcji. Wydanie tych bibliografii, a szczególnie pracy Manuel du libraire et de l'Amateur des livres, ogromnie wzmogło zainteresowanie książką rzadką, cenną i poszukiwaną, przyczyniając się clo wiellkiego wzrostu liczby kolekcjonerów i miłośników książki. Z drugiej zaś strony wspomniany Dahl wlaśnie J. Ch. Bruneta obarcza dziś odpowiedzialnością za jednostronność francuskich kolekcji książek i za windowanie cen, za jakie były sprzedawane na aukcjach XIX i XX w. te książki, które szczególnie wyróżnił Brunet. Ta uwaga Dahla tylko podkreśla wpływ Bruneta na francuską (i nie tylko) bibliofilię ${ }^{4}$.

Bibliofilstwo francuskie, $z$ którego w znacznym stopniu w okresie międzywojennym czerpały swe wzory organizacyjne i metody działalności niektóre polskie stowarzyszenia bibliofilskie, pierwszą organizację bibliofilską stworzyło już w 1820 r. Było nią, powołane z inicjatywy René-Charlesa Guilberta de Pixérécourta (1773-1844) francuskiego dramaturga, Towarzystwo Bibliofilów Francuskich (Société des Bibliophiles Français) w Paryżu. Bylo to najbardziej elitarne z francuskich stowarzyszeń miłośników książki, którego liczbę czlonków ograniczono clo 35 osób (w czym mogły być i kobiety, ale nie więcej niż pięć), wybieranych na wolne „fotele” po ich opróżnieniu. Byli to przeważnie przedstawiciele starych historycznych rodów arystokratycznych (np. w 1898 r: towarzystwo zrzeszało 28 członków, wyłącznie utytułowanych: książąt, markizów, hrabiów, baronó $w^{5}$ ) posiadających bogate zbiory i archiwa, często wykorzystywane przy sporząclzaniu facsimilów publikacji bibliofilskich. Głównym celem stowarzyszenia było właśnie ogłaszanie nieznanych prac $z$ dziedziny historii, literatury i języka francuskiego oraz „pielęgnowanie w tych wydlawnictwach clawnej tradycji drukarskiej"6. Towarzystwo w swoich zbiorach posiadało cenną kolekcję czcionek dawnych drukarzy francuskich, a wydawnictwa, których do $1939 \mathrm{r}$. opublikowano kilkadziesiąt, odznaczają się przede wszystkim doskonałym czer- 
panym papierem ze znakami wodnymi, pięknym drukiem, zgodnie $z$ kanonem typografii antiquo modo. Oprócz 35 imiennych egz. dla członków towarzystwa (na specjalnym papierze), niektóre $z$ tych wydawnictw tłoczone są nadto w ograniczonym nakładzie 100-200 egz. przeznaczonych do handlu księgarskiego. Jedyną pozycją tego stowarzyszenia, jaką uclało mi się zobaczyć, jest wspaniale wydanie autorstwa Henri d'Orléans, duc d'Aumale La Bataille de Rocroy (1899) $z$ akwafortami (kolorowanymi) Adolphe Lalauze, w nakładzie 144 egz. Do publikacji tego stowarzyszenia należy też m.in. Jeana de Lafontaine'a Adonis (1931) wydany w nakładzie $130 \mathrm{egz}$, oraz znakomita Histoire du Papier... Louisa Le Clert (1926).

Jako następne powstało w 1835 r. Les Cent Bibliophiles. Składało się ono ze 100 członków $z$ wyboru. Wydawnictwa tego zrzeszenia drukowane były w 130 egz. (30 clla współpracowników i do dyspozycji zarządu). Są to przeważnie bogato ilustrowane teksty współczesnych autorów, których wydano dotychczas kilkadziesiąt tomów ${ }^{7}$.

W 1874 r. powstało Towarzystwo Przyjaciół Książki (La Société des Amis du Livre), założone przez Eugéne Pailleta oraz Henri Béraldiego ${ }^{8}$. Ma na celu nawiązywanie i zacieśnianie stosunków między amatorami pięlknych książek we Francji i poza jej granicami. Liczba członków stowarzyszenia ograniczona jest do 125, ale w praktyce często nawet jej nie osiąga (w 25 lat po utworzeniu Towarzystwo w r. 1898 liczyło 63 członków zwyczajnych +24 członków-korespondentów ${ }^{9}$ ), a kandydaci muszą przejść dość skomplikowaną procedurę i być przyjęci poprzez głosowanie. Stowarzyszenie gromadzi w swych szeregach przedstawicieli burżuazji i inteligencji francuskiej: adwokatów, architektów, notariuszy, literatów etc. oraz sporą grupę bibliofilów z zagranicy. Składlka członkowska w okresie przedwojennym była wysoka (100 fr. wpisowego, 200 fr. skladki rocznej), ale w zamian członkowie otrzymują bezpłatnie wszystkie wyclawnictwa, które stoją na niezwykle wysokim poziomie edytorskin, publikowane wręcz luksusowo i ozdabiane ilustracjami najwybitniejszych artystów francuskich. Publikacji tych, odbijanych w nakłaclzie do $150 \mathrm{egz}$. (w tym 25 dla współpracowników) do wybuchu II wojny światowej wydano około 50 . Z wydawnictw tego stowarzyszenia znany mi jest jedynie utwór Leconte de Lisle Poémes antiques (1908) z 30 ilustracjami Maurice Ray'a, wydany w nakładzie $110 \mathrm{egz}^{10}$.

W latach osiemdziesiątych XIX w. utworzono w Paryżu Académie des Beaux Livres. Prezydentem tej instytucji został Octave Uzanne, a wice-przewodniczącymi Henri Beraldi oraz Charles Cousin. Przy Alkademii powstało stowarzyszenie zwane Les Bibliophiles Contemporains, które zlołało opublikować kilka wydawnictw, ilustrowanych przez wybitnych współczesnych grafików książkowych takich, jak: Géry-Bichard, Alexandre Lunois, Eugéne Courboin, Carlos Schwabe, Aleksandre Seon, Georges Rochegrosse, czy rytowanych przez takich, jak: Félicien de Rops, van Muyden, Paul Avril, Boulet, Gervais, Gueldry, Jeanniot, Morel, Scott, Viclal, Fornet, Manesse i inni. Poza pięcioma tomami "Annales Littéraires" AdBL, wydanymi w latach 1889-1894, nakładem Les Bibliophiles Contemporains ukazały się: Edmonda Haraucourta L'Effort... (1894, w nakł. 180 egz.), Guy de Maupassanta Contes Choisis (1891-1892, w nakł. 188 egz.), Jeana Richepina Les Débuts de César Borgia (1890, w nakł. 186 egz.), 
Stendhala L'Abbesse de Castro (1890, nakł. 190 egz.) oraz Octave Uzanne Dictionnaire bibliophilosophique (1896, nakk. 176 egz.) i kilka innych.

Kolejne stowarzyszenie utworzone jeszcze w XIX stuleciu to tak zwane Ia Société des XX. Powstało ono w 1897 r. i jak sugeruje nazwa składa się zaledwie $z 20$ członków. Było to nadzwyczaj ekskluzywne towarzystwo, typu zakonu bibliofilskiego.

W 1903 r. powstało Société du Livre Contemporain. Statutowo liczy 104 członków, wśród których jest pewna liczba cudzoziemców. Członkowie tego zgromadzenia interesują się głównie literaturą współczesną i tego też zakresu wyłącznie tyczą wyclawnictwa stowarzyszenia. Do wybuchu II wojny światowej SdLC opublikowało około 30 utworów, w nakładzie 110-125 egzemplarzy.

Rok później (1904) utworzono La Société du Livre d'Art. Posiadlało ono podobny charakter do poprzedniego, liczba członków również była ograniczona do 100, nadto przewiclziana była kategoria członków-korespondentów w liczbie 20, którzy mogli stawać się członkami rzeczywistymi w miarę zwalnianych miejsc. Stowarzyszenie zgodnie $z$ nazwą zajmowało się książką artystyczną w formie i samo też publikowało podobne edycje, które drukowano w nakłaclzie 125 egzemplarzy. Dorobek wydawniczy stowarzyszenia nie był pokaźny, zamykał się liczbą kilkunastu tomów.

Jeden z czlonków tego stowarzyszenia, Charles Meunier, znakomity introligator, twórca wielu wspaniałych opraw mozaikowych - powołal do zycia w $1908 \mathrm{r}$. kolejne towarzystwo bibliolilskie - La Société des Amis du Livre Moderne. Statutowo mogło ono gromadzić do 125 członków, a druki publikowane przez to stowarzyszenie nie przekraczały 150 egz. nakładu. Zrzeszenie to znane jest mi m.in. z utworu Maurice Larrouy L'odlyssée d'un transport torpillé, wydanego w 1923 r. $z$ ilustracjami Charlesa Fouqueray.

„Przed wojną bibliofile stanowili dość zamknięte grono ludzi, pewnego rodzaju wolnomularstwo książki - poza które wydawnictwa rzadkie i cenne rzadko wychodzily [...] Spekulacja handlowa tymi wydawnictwani prawie że nie istniala; przeciętny amator mógł je clostać wypadkowo, po śmierci jednego z uprzywilejowanych, ale i to najczęściej nabywał je na licytacji jeden $z$ czlonków ograniczonego koła bibliolilów"11.

Po I wojnie światowej ten stan rzeczy ,zupełnie się zmienił i to jest bodaj najbardziej charakterystyczna cecha bibliofilstwa francuskiego (...) Uległo ono demokratyzacji i rozrostowi; książka zbytkowna i rzadka stała się codziennym i bieżącym produktem..."12. Kazimierz Woźnicki, z którego rozprawy cytowałem ów fragment, przytacza następnie kilka charakterystycznych liczb: w $1914 \mathrm{r}$. istniało we Francji osiem towarzystw bibliofilskich, liczących około 600 członków; w 1933 r: istniało już trzydzieści jeden ważniejszych, liczących 3500 członków, a nadto dziesiątki drugorzędnych towarzystw, rozpoczynających clopiero swą działalność. Towarzystwa bibliofilskie w latach 1820-1914, tj. przez ponad dziewięćdziesiąt lat ogłosiły 221 tomów, zaś od 1918 r. do 1932 r., tj. przez lat czternaście tomów $338^{13}$.

Jak wspomniano clalsze towarzystwa bibliofilskie we Francji powstały juz po zakończeniu wielkiej wojny. Ich cechą najbardziej charakterystyczną było to, iz w wielu przypadkach zrzeszenia te grupowały członków wyłącznie jednakowej profesji. Wprawdzie zdarzało się to już wcześniej, czego przylkładem może byc 
La Société de la gravure sur bois originale, założone w 1905 r., które miało podobny zamknięty charakter, zawężony do kręgu autorów i artystów drzeworytników. Grupowało ogółem do 140 członków, podzielonych na trzy kategorie: członków stowarzyszonych (30 artystów Francuzów), członków tytularnych (100 amatorów Francuzów i cudzoziemców) oraz czlonków-korespondentów (10 artystów cudzoziemców). Członkowie wykonywali artystyczne ilustracje, które otrzymywali wszyscy stowarzyszeni w postaci oryginalnych odbitek, sygnowanych przez twórców. Towarzystwo publikowało także druki bibliofilskie, w ograniczonej liczbie egzemplarzy, których do czasu II wojny wyszło ponad 20.

W 1920 r. założono La Société des Medecins Bibliophiles - bibliofilskie stowarzyszenie lekarzy, składające się ze 100 członków zwyczajnych oraz 20 członków-korespondentów. Stowarzyszenie to wydaje publikacje, które ukazują się w maksymalnym nakładzie 200 egzemplarzy.

Kilka lat później powstało kolejne towarzystwo zrzeszające lekarzy pod nazwą Hippocrate et ses amis. Utworzone w 1924 r., statutowo zawężone do $100 \mathrm{czlon}-$ ków, nie zaznaczyło szerzej swojej obecności, ograniczając się do wyclania zaledwie kilku publikacji. Przynależność do tego stowarzyszenia wiązała się w okresie międzywojennym $z$ największymi wśród wszystkich towarzystw obciążeniami finansowymi, wynoszącymi $500 \mathrm{fr}$. wpisowego oraz 1000 fr. składki rocznej.

Także i francuscy aptekarze założyli swoje stowarzyszenie bibliofilskie pocl nazwą La Société des Pharmaciens Bibliophiles. Powstało ono w 1928 r., było dosyć liczne (150 członków) i publikowało wydawnictwa, które treścią swą wiązały się $z$ wykonywanym zawodem czlonków zgromadzenia. Nakład tych numerowanych druków odpowiadał dokładnie liczbie zrzeszonych uczestników Towarzystwa, ponadto clrukowano tė̇ kilka egzemplarzy dla współpracowników, oraz 2 egzemplarze na sprzedaż.

Kolejne towarzystwa zakłaclane przez ludzi określonej profesji to między innymi: Les Bibliophiles du Palais, a także La Société St. Eloy. Pierwsze $z$ nich powstało w 1923 r. i składa się wyłącznie z prawników, których może być maksymalnie 155. Członkami moga być też cudzoziemcy - oczywiście wyłącznie przedstawiciele palestry - w liczbie nie większej niz 20-tu. Przedmiotem szczególnej uwagi Towarzystwa były wydawnictwa bibliofilskie tematycznie związane $z$ wykonywanym zawodem, bądź których autorami byli prawnicy. Publikacje te byly drukowane $w$ nakładzie 200 egzemplarzy, nader wytwornie, $z$ dużą liczbą ilustracji $w$ technice litografii, drzeworytu bądź akwaforty. W omawianym przeze mnie olkresie wydlano m.in. Arystofanesa La Paix (1930), Honoré de Balzaca Le Colonel Chabert (1924), Anthèlme Brillat-Savarina Aphorismes et Variétés (1940), Sidonie-Gabrielle Colette La Vagabonde (1928), Catherine Fredonnoit La Puce de Madame des Roches (1936), Marie-Magdeleine Pioche de la Vergne, comtesse de Lafayette La Princesse de Cléves (1930). Wśród innych autorów spotykamy następujące pozycje: Jules Michelet La Genése de la Mer (1937), Charles-Louis de de Ségondat Lettres Persanes (1926), Jean Racine Les Plaideurs (1932), Romain Rolland Le Jeu de l'Amour et de la Mort (1924), André Suares Cité, Nef de Paris... (1933) czy dwie pozycje Paula Verlaine'a: Les Poétes maudits (1938), oraz Romances sans Paroles... (1934). Towarzystwo to istnieje nadal i publikuje swe wydawnictwa w identycznym, jak przed wojną, nakładzie $200 \mathrm{egz}$. 
La Société St. Eloy natomiast to stowarzyszenie założone w 1924 r., grupujące głównie jubilerów oraz grawerów, których statutowo może być 100, a także pewną liczbę artystów (w 1933 r. było ich 17-tu), zobowiązanych do określonych świadczeń na rzecz zgromadzenia (są to zwykle ilustracje do publikacji własnych Towarzystwa, w zamian artyści płacą zaledwie jedną piątą bardzo wygórowanej składki rocznej, wynoszącej 500 fr.). Ciekawostlką jest, iż statut stowarzyszenia wykluczał członkostwo księgarzy i handlarzy rycinami. Wytworne wydawnictwa stowarzyszenia (zresztą nieliczne) drukowane byly w liczbie 127 egz. numerowanych i bogato ilustrowanych, zwykle przez kilku artystówgrafików.

$Z$ innych grup zawodowych czy społecznych, a nawet przedstawicieli róznych plci, bądź określonych zamiłowań artystycznych, w które w okresie międzywojennym obfitował francuski zrzeszony ruch bibliofilski, wymienić można jeszcze kilka stowarzyszeń, których członkani mogły być wyłącznie kobiety. Pierwsze $z$ nich powstało w $1925 \mathrm{r}$. pod nazwą Les Cent-Une. Zgodnie $z$ tą nazwą liczba członkiń wynosi 101. Towarzystwo pań-bibliofilek przetrwało do II wojny, publikując własnym nakładem kilka wydawnictw, w nakładzie 120 egz.

Kolejne stowarzyszenie, ograniczające członkostwo wyłącznie do przedstawicielek płci pięknej, utworzono w 1927 r., jako Les cent Femmes amies des livres. Tych „przyjaciółek książki” może statutowo być sto, a ich istotnie feministyczne nastawienie znalazło $\mathrm{w}$ statucie wyraz $\mathrm{w}$ stwierdzeniu, $\mathrm{i} \dot{z}$ wydawane własnym sumptem (w nakładzie 120 egz.) utwory mogą pochodzić wyłącznie spod kobiecego pióra.

O trzecim stowarzyszeniu kobiecym o nazwie La Société bibliophiles de femmes, nic mi bliżej nie wiadomo.

Do ciekawostek należy zaliczyć istnienie tak „wyspecjalizowanych” stowarzyszeń bibliofilskich, jak Les Bibliophiles du Aero-Club de France (założone 1930), czy Les Bibliophiles de l'Automobile-Club de France (założone 1929). Oba były dość liczne (automobiliści posiadali 100 członków, lotnicy 150-ciu). Będąc jednocześnie członkami macierzystych klubów, reprezentowali zgodne $z$ tym zainteresowania i teoretycznie zakladali statutowo publikowanie ( $w$ artystycznej formie) utworów o tematyce związanej $z$ ich przynależnością klubową. W praktyce nakładem obu tych stowarzyszeń ukazywały się wydawnictwa (w nakładach stosownych do liczby członków) o bardzo różnorodnej tematyce. Tak np. w dorobku Automobile-Clubu spotykamy takie pozycje, jak: Théodore de Banville'a La Mer de Nice (1933), trzy utwory Pierre Bellanger'a: Apsis (1930), Discours de réception (1929) oraz Supplément aux Destinées d'Alfred de Vigny (1929), Tristana Dereme L'Enlévement sans clair de Lune (1931), Homera L'Odyssée (1930-1933), René Marana Le Livre de la Brousse (1937), Marcela Schwoba Mimes... (1933). Spotykamy też takie pozycje, jak: Paul-Ambroise Valéry Mélange de Prose et de Poésie (1939) oraz Alfred de Vigny Les Destinées... (1929). Także to stowarzyszenie bibliofilskie kontynuuje działalność w okresie powojennym.

$Z$ ciekawszych publikacji wydanych natomiast przez bibliofilów-lotników, można wymienić Cyrano de Bergerac Voyage dans la Lune (1932) oraz Josepha Kessela Vent de sable (1931). 
W 1927 r. powstało specyficzne towarzystwo bibliofilskie pod nazwą Les Bibliophiles du Papier. W zgromadzeniu tym „normalni” bibliofile stanowili około $80 \%$ członków, reszta miejsc zarezerwowana była dla przedstawicieli przemysłu papierniczego, poligraficznego oraz księgarzy. Alktywne to stowarzyszenie, już w pierwszym roku działalności, ogłosiło drukiem utwór Paul-Louisa Courier'a Lettres de France et d'Italie (1927). Pierwsze publikacje (w latach 1927-1931) wychodzily w nakładzie $110 \mathrm{egz}$., od połowy $1931 \mathrm{r}$. kolejne wydawnictwa zrzeszenia zwiększały nakład (122-125 egz.). Wśród tych publikacji były: Honoré de Balzac Histoire de la Grandeur et de la Décadence de César Birot teau (1933), Boursault Treize Lettres amoureuses (1932), Andre Chamson Les Hommes de la route (1935), Victor Hugo Les Burgraves (1930), Jean Moreas Les Stances (1929), Aeneas-Sylvius Piccolomini Euryale et Lucréce (1931), Thomas Raucat L'Honorable partie de compagne (1928), F.M. Voltaire CosiSancta (1934) i inne.

Oprócz wymienionych, podobny charakter „zamkniętego” stowarzyszenia nosiło Les Bibliophiles du Faubourg, powstałe w 1928 r. Członkami tego zrzeszenia byli przedstawiciele bardzo we Francji rozbudowanego przemysłu dekoracyjnego, głównie wytwórcy mebli stylowych. Ponieważ główne siedlisko tego rzemiosła znajduje się w Paryzu, na Faubourg St.-Antoine (popularnie znanym jako „Le Faubourg") stąd też nazwa stowarzyszenia. Liczba członków bardzo się waha i oscyluje zazwyczaj między 40-100 osobami. Towarzystwo publikuje swoje wydawnictwa w nakładzie do $110 \mathrm{egz}$. Wśród utworów, które ukazały się pod szyldem stowarzyszenia spotykamy: Auguste Angellier A l'Amie perdue (1929), Franc-Nohain Cinquante fables (1928), Jean Giono Naissance de I'Odyssée (1935, jako jedyny druk wydany w nakł. 120 egz.), Maurice Levaillant Ames et Paysages de l'Ile-de-France (1932) czy Géo Michel Notre vieux Faubourg (1934).

W ostatnich latach przed wybuchem II wojny światowej połączyły się oba wymienione wyżej stowarzyszenia w jedno zgromadzenie pod nazwą Les Bibliophiles du Faubourg et du Papier, wydając m. in. utwór Rogera Devigne Menilmontant (1937, w nakł. 135 egz.), Henri Pourrata Gaspard des Montagnes (1938, nakk. 140 egz.), Stendhala Ernestine ou la Naissance de l'Amour (1939, nakł. 120 egz.). Towarzystwo istnieje nadal i prowadzi nader ożywioną działalność.

Towarzystwa takie, jak np. Les Exemplaires (utworzone 1924, liczące 99 członków) czy stanowiące jego odpowiednik w zakresie publikowania ciekawych i rzadkich broszur Les Plaquettes - nie rozwinęły szerszej działalności, ograniczając się clo wydania kilku tomików druków bibliofilskich, w ograniczonym do stu kilku egzemplarzy nakładzie. Również brak pewnej rzutkości daje się zauważyć w pracach stowarzyszenia pod nazwą Les Eclestiques du Livre (założonego w 1928 r.), które liczyło około 150 członków, i w takiej też liczbie publikowało swe wydlawnictwa oraz 30 egz. dla współpracowników. O kolejnym zgromadzeniu pod nazwą Les Bibliophiles Fantaisistes wiadomo mi tylko, iż w 1923 r. opublikowało utwór Claude Farrere Trois Histoires d'ailleurs, w ogromnym jak na druk bibliofilski nakładzie $1100 \mathrm{egz}$.

Podobnie niewiele da się powiedzieć o kilku innych stowarzyszeniach bibliofilskich o mniejszym znaczeniu, jak: Les Centraux Bibliophiles (powołane do 
życia w 1926 r., którego członkami byli wyłącznie absolwenci Sorbony, w liczbie 100 - wydawało nieliczne publikacje w nakładzie $130 \mathrm{egz}$.), czy Les Parallèies (założone 1928, liczące 120 członków, którego jednym z zadań statutowych było publikowanie - głównie w przedrukach faksymilowych - rzadkości bibliograficznych).

Warto jeszcze wspomnieć o istnieniu Les Bibliophiles du Cornet, specjalnej grupy bibliofilskiej, utworzonej w 1929 r., w łonie głośnego towarzystwa literackiego „Le Cornet” w Paryżu. Duża, bo licząca 150 członków, sekcja bibliolilska wydlała do wybuchu wojny kilka ciekawych druków (w nakładzie 175-200 egz.), wśród których znalazły się m.in. następujący autorzy i ich prace: Louis Codet La petite Chiquette (1932), Maurice-Charles Donnay Education de prince (1931), Edmond Haraucourt Autre Temps (1930), Raoul Ponchon Fantaisies et Moralités (1935).

Podobny charakter posiadało Le Cercle parisien du Livre, utworzone w $1926 \mathrm{r}$., które bylo pewną kontynuacją nieformalnego grona miłośników książki, skupionych przy Librairie des Bibliophiles Parisiens na początku lat dwudziestych $^{14}$. Skład tego zrzeszenia obejmowal przede wszystkim ludzi związanych z szeroko pojętą kulturą ksiązki: księgarzy, introligatorów, drukarzy, bibliotekarzy, ale wśród grona bibliofilów, jako czlonkowie występują też technicy i ludzie innych zawodów. Charakterystycznym punktem statutu stowarzyszenia było zadanie „wyszukiwania” i promowania nieznanych dotychczas a utalentowanych grafików książkowych. Liczba członków nie mogła przekraczać 100 osób, a nakłady publikacji tego towarzystwa 130 egz.

Ograniczony krąg członków charakteryzował kolejne paryskie zrzeszenie pod nazwą Les Bibliophiles de Montmartre. Skupiało ono głównie świat artystyczny, malarską cyganerię tej dzielnicy. Towarzystwo to kontynuowało swą działalność także po Il wojnie światowej, z przedwojennych wydawnictw znane mi jest z książeczki Georgesa Courteline Les Linottes (1937) z akwatintami A. Puyplata.

Oddzielne miejsce należy się Les XXX, towarzystwu powstalemu w $1928 \mathrm{r}$, które dzieliło członków na dwie kategorie: „rzeczywistych”, posiadających wszelkie prawa i przywileje organizacyjne, a których liczba nie mogła przekroczyć 30, oraz członków „pozostałych”, których mogło być dowolnie dużo, lecz pozbawionych uprawnień, oczekujących na ewentualne wakaty, z których pomocy finansowej czy wiedzy zawodowej korzystano jednak przy wydawaniu publikacji, lub innej działalności statutowej. Wydawnictwa drukowano w nakładzie 120 egz., z czego zwyczajowo połowę otrzymywał artysta-grafik, ilustrujący publikację - jako swego rodzaju honorarium.

Z towarzystw regionalnych najwcześniejszym było, założone w lutym $1866 \mathrm{r}$ : w Bordeaux, Société des Bibliophiles de Guyenne. W momencie zakładania liczba członków zrzeszenia obejmowała 59 nazwisk $^{15}$. Towarzystwo to od $1868 \mathrm{r}$. wydawało Publications de la Société des Bibliophiles de Guyenne, wspaniale redagowane czasopismo o charakterze historyczno-literackim.

Następne $z$ regionalnych zrzeszeń to La Société Normande clu livre illustré. Powstałe pod koniec XIX stulecia działało do 1921 r., kiedy to jego działalność została zawieszona. Towarzystwo to w okresie prawie trzydziestoletniej pracy opublikowało około 20 bardzo pięknych książek. W 1929 r. wznowiono dawne 
towarzystwo pod nieco zmienioną nazwą Les Nouvelle Société Normande du livre illustré, a jego głównym celem stało się ogłaszanie wydawnictw o tematyce tyczącej prowincji oraz książek autorów pochodzących z Normandii.

Stowarzyszenie bibliofilów prowansalskich, z siedzibą w Tulonie, wydało przed wojną szereg wytwornych druków, bądź tyczących tego regionu, bądź autorzy których pochodzili z Prowansji. Są tu m.in. prace Téodora Aubanel Lou Libre de l'Amour (1928) wydane w 125 egz. na czerpanym holenderskim papierze, Henri Bosco Le Trestoulas (1937) z wspaniałymi ilustracjami Edy Legranda, uważanego za jednego $z$ odnowicieli francuskiej sztuki ilustracyjnej, szczególnie litografii; dalej praca Marcela Briona La Reine Jeanne (1936), interesujące wspomnienia $z$ podróż Claude Lhuillera zwanego Chapelle i François Le Coigneux zwanego De Bachaumont (1933), Jeana Giono Regain (1933) - wszystkie w nakładzie 150 egz.; ponadto prace Maurice de Guerina Le Centaure et la Bacchante (1929), Ninon de Lenclos listy do de St-Evremonda (1927), Frécléricka Mistrala Nerte (1936) i inne. Towarzystwo Bibliofilów Prowansalskich istnieje nadal i publikuje wspaniałe druki w limitowanych nakładach 30-412 egz.

Dużą aktywność przejawiało zrzeszenie miłośników książki w Besançon, obejmujące głównie członków departamentu Doubs, a szerzej Franche-Comté (czyli Jury). Stowarzyszenie to pn. Les Bibliophiles Comtois propagowało w swoich wydaniach twórczość pisarzy lub ludzi nauki pochodzących z regionu, takich, jak Victor Hugo (urodzony w Besançon), którego L'Aigle du Casque opublikowano w 1928 r., czy Louis Pasteur (ur. w Dôle), z wydanymi Lettres et Discours (1927). Wśród innych publikacji znalazły się: Honoré de Balzac Albert Savarus (1930), Sidonia-Gabrielle Colette La Retraite Sentimentale (1932), Charles Jouas, A. Monnot Besançon (1938), pamiętniki Alphonse Lamartine wydane w $1933 \mathrm{r}$. i ozdobione oryginalnymi akwafortami oraz szereg innych. Po II wojnie światowej towarzystwo działa nadal i obdarzyło swoich członków pięknymi drukami m.in. autorstwa André Malraux, Owidiusza, Louisa Pergauda, Platona, Ernesta Renana, Anatole France'a, Arthura Rimbaud oraz Woltera.

Kolejne regionalne stowarzyszenie zawiązano w 1921 r. Jest to Le Cercle lyonnais du Livre, złożone przeważnie $z$ bibliofilów lyońskich czy szerzej regionu Rhônes-Alpes. Koło to obejmowało blisko 150 członków i zazwyczaj w takiej mniej więcej liczbie (150-175 egzemplarzy) drukowało swoje wydlawnictwa. Do wybuchu ostatniej wojny nie rozwinęło szerszej działalności publikując nieco ponad 10 utworów.

Jednym $z$ najmniejszych stowarzyszeń bibliofilskich we Francji było Les Bibliophiles de Nice, powolane do życia w 1927 r. Zgromadzenie to liczyło 25 członków.

Jeszcze mniejszym okazało się stowarzyszenie pod nazwą Les Bibliophiles du Nord (utworzone 1927). W 1929 r. liczylo zaledwie 15 członków, ale wykazywało znaczną aktywność. Z powodu tak ograniczonego grona uczestników tego zgromadzenia nie było w stanie samodzielnie publikować swoich wydawnictw, uciekało się więc do wielokrotnie wypróbowanej już we Francji praktyki, zamawiania u wydawców pewnej części „normalnego" nakładu książki, z uwzględnieniem jednakże wszystkich tzw. „smaczków” bibliofilskich, jak specjalny papier, ilustracja i oprawa. 
Typowo lokalnym towarzystwem było Les bibliophiles alesiens, zalożone w Ales (do 1926 Alais) w południowej Francji, które znane mi jest wyłącznie $z$ jednej publikacji, wydanej w $1942 \mathrm{r}^{16}$.

Na koniec trzeba przynajmniej wymienić pozostałe stowarzyszenia francuskich miłośników książki, które powstawały w różnych miastach i miały na ogół takze lokalny charakter:

Les Bibliophiles d'Auvergne - było stowarzyszeniem bibliofilów regionu Owernii, o którym nic bliższego nie potrafię powiedzieć, znane jest mi bowiem zaledwie $z$ jednej publikacji1"

La Société des Bibliophiles du Béarn - grupowało bibliofilów z wschodniej części obecnego departamentu Basses-Pyrenées, $z$ ośrodkiem w Pau.

La Société des Bibliophiles de Bourgogne - stowarzyszenie miłośników ksiazki z historycznej Burgundii.

La Société des Bibliophiles nimois - stworzone przez bibliofilów $z$ departamentu Gard (Langwedocja), którego ośrodkiem administracyjnym jest miasto Nîmes.

La Société des Bibliophiles de Reims - którego członlkami byli zarówno bibliofile miejscowi, jak też $z$ terenu Szampanii.

La Société rouennaise de Bibliophiles - stowarzyszenie z Rouen, głównego ośrodka departamentu Seine-Maritime w Normandii.

Do wybuchu II wojny światowej liczba ważniejszych towarzystw bibliofilskich we Francji przekroczyła 30.

W pewnym związku $z$ ruchem bibliofilskim pozostawały także stowarzyszenia miłośników różnych form graficznych, jak chociażby La Société des Amis de l'eauforte.

We Francji działały też stowarzyszenia bibliofilskie obejmujące członków różnych narodowości, jak np. Polskie Towarzystwo Przyjaciół Książki w Paryżu (Société Polonaise des Amis du Livre), jedyne $z$ polskich towarzystw bibliofilslkich na obczyźnie (1924-1955), które zdołało rozwinąć ożywioną działalność na rzecz polskiej książki, czy Obščestvo Druzej Russkoj Knigi (Société des Amis du Livre Russe - Towarzystwo Przyjaciól Książki Rosyjskiej), działające w Paryzu przy rue Claude-Lorrain 2, w latach 1923-1939, które w okresie swego największego rozkwitu liczyło 126 członków (w tym 23 spoza Paryża ${ }^{18}$ ).

Na koniec warto wspomnieć o szeregu towarzystw bibliofilskich francuskojęzycznych, działających na terenie innych państw czy krajów, lub towarzystw mieszanych francusko-zagranicznych. Należały, lub należą, do nich w dalszym ciągu, takie stowarzyszenia, jak:

La Société des Bibliophiles africains.

La Société des Bibliophiles créoles, założone w Papeete na wyspie Tahiti (Wyspy Towarzystwa) administracyjnym ośrodku Polinezji Francuskiej, grupowało lokalnych bibliofilów, którzy nawet podejmowali pewną działalność wydawniczą ${ }^{19}$.

La Société bibliophile France-Amérique-Latine założone w 1926 r. jako La Compagnie des bibliophiles du Livre d'art et de l'Amerique Latine miało na celu zbliżenie bibliofilów francuskich $z$ ich francuskojęzycznymi kolegami $z$ Ameryki Łacińskiej (głównie Gujany Francuskiej). Już w pierwszym roku działalności stowarzyszenie wydało własną publikację, którą byl utwór Gérarda d'Hou- 
ville Le Séducteur (1926, nakł. 150 egz.). W latach następnych ukazały się: Marc Chadourne Vasco (1931), F.-R. Chateaubriand Les Aventures du Dernier Abencérage (1930), Garcia Calderon La Vengeance du Condor (1929), Jean Giono Un de Baumugnes (1930), Enrique Larreta La Gloire de Don Ramire (1934). Towarzystwo wznowiło działalność i publikacje po II wojnie światowej.

La Société des bibliophiles du Maroc, istniało w Casablance od końca lat dwudziestych do co najmniej 1942 r., musiało być dosyć liczne, gdyż swe publikacje drukowało w nakładach po 150 egz., na doskonałym czerpanym papierze $z$ Arches. Byly to utwory o tematyce kolonialnej, m.in. Maurice'a Leglay'a Trois Récits marocains... z akwarelami Abascala, czy Prospera de Mérimée Djoumane... $z$ alkwafortami de Barta.

Istniejące w okresie mięclzywojennym w Brukseli francuskojęzyczne stowarzyszenie o nazwie Société des Bibliophiles et Iconophiles de Belgique - grupowało zarówno miłośników ksiązki, jak też grafiki artystycznej. Swoje publikacje wydlawało w nakładzie 150-160 egz. Wśród nich znalazły się przylkładowo utwory Alberta Girauda Le Laurier z alswafortami Constanta Dratza (1921) czy Camille Lemonnier Un Male, z litografiami Roméo Dumoulina (1921).

Kolejnym francuskojęzycznym stowarzyszeniem w Belgii było La Société des Bibliophiles belges, znane mi m.in. $z$ wydanej w $1924 \mathrm{r}$. w Brukseli książki Charlesa Van Lerberghe La Chanson d'Eve z litografiami Josa Bouvaerta.

La Société des Bibliophiles de Liège - obejmowało swym zasięgiem zarówno bibliofilów $z$ tego miasta, jak też i $z$ regionu.

W Antwerpii (franc. Anvers) w północnej Belgii powstało La Société des bibliophiles anversois.

Lokalnym towarzystwem bibliofilskim było też La Société des Bibliophiles de Mons (flamandzkie Bergen), w administracyjnym ośrodku prowincji Hainaut w zachodniej Belgii.

Jednym $z$ najbardziej aktywnych stowarzyszeń francuskojęzycznych jest do dziś dnia La Société cles Bibliophiles franco-suisses, którego siedziba mieści się w Paryżu. Grupuje ono zarówno miłośników książki z terenu Francji, jak też frankofonskich kantonów Szwajcarii. Powstało pod koniec lat dwudziestych i swej ożywionej działalności nie przerwało nawet w okresie II wojny światowej, kiedy to opublikowano szereg druków ${ }^{20}$. Nakłady tych wydawnictw w okresie przedwojennym wahały się w granicach 110-160 egz. (większość utworów wydano w nakł. 115 egz.). Są wśród nich następujący autorzy: Louis Barthou Les Amours d'un Poéte (1933), Jean Exbrayat Louis Barthou de L'Académie Franfaise (1934), John Gay L'Opéra du Gueux (1934), Jacques-Charles Mardrus Le Marié magique (1930), Roger Martin du Gard Vieille France (1935), François Mauriac Génitrix (1937), Jules Michelet Tableau de la France (1936), Henry de Montherlant Les Bestiaires (1932), Gerard Nerval La Main enchantée (1938), Charles-Ferdinand Ramuz Farinet (1938).

W kanadyjskiej prowincji Quebec działało La Société Royale du Canada. 


\section{Wydawnictwa bibliofilskie}

Większość wymienionych powyżej towarzystw miłośników książki, poza innymi zadaniami statutowymi, jak: prelekcje, wystawy, wycieczki, aukcje etc., na pierwszym miejscu stawiała także publikowanie własnych „wzorowych pod względem typograficznym" luksusowych wydawnictw bibliofilskich.

Dawne, a zwłaszcza te najstarsze towarzystwa bibliofilskie dbały przede wszystkim o poprawny tekst, a wzgląd na stronę formalną publikacji tych "les grands écrivains", przejawiał się głównie w doborze pięknych czerpanych ręcznie papierów, klasycznym układzie kolumny, szerokich marginesach i pięknym starannym druku. Dopiero ostatnie ćwierćwiecze XIX stulecia przyniosło zainteresowanie książką ilustrowaną, która stała się odtąd głównym obiektem pożądań bibliofilskich. Stąd też charakterystyczną cechą francuskich wydawnictw bibliofilskich, jest bardzo bogata szata ilustracyjna. Jedyne odstępstwo od tej zasady uczyniło La Société des Bibliophiles Français, którego publikacje mają na względzie głównie telist (jrace $z$ dziedziny historii, literatury i języka francuskiego), a ich strona artystyczna polega jedynie na doskonałym papierze i tradycyjnym druku odbijanym w najlepszych oficynach paryskich.

Jeśli chodzi o techniki ilustracyjne to we francuskich drukach bibliofilskich występują zarówno drzeworyty, jak też litografia i różne techniki metalowe (z tych najrzadziej miedzioryt, a najczęściej akwaforta). Francuscy peintre-graveurzy w wielu przypadkach w jednym wydawnictwie zamieszczali do 50 oryginalnych grafik. Powstały też dosyć liczne stowarzyszenia tych artystów, jak np. Société des Aquafortistes, Société Française de Gravure i l'Eau forte (1868) i wiele innych, których założeniem było popieranie grafiki artystycznej, jako przeciwwagi masowym technikom reprodukcyjnym (fototypicznym). Wydawane przez stowarzyszenia bibliofilskie te „livres clu peintre” stanowily swoiste dzieła sztuki, a stosowana tu oryginalna grafika (po wydaniu książki płyty $z$ reguły niszczono) była clostępna barclzo nielicznym koneserom i miłośnilkom książki.

Wszystkie francuskie publikacje bibliofilskie tłoczone są $z$ reguły na papierze czerpanym ewentualnie na welinie. Do najbardziej luksusowych wydawnictw stosowano papier chiński lub japoński (produkowany $z$ wewnętrznego miąższu morwy papierowej), a liczne prywatne papiernie francuskie dostarczały znakomitej jakości produktów, głównie takich, jak vélin de Rives nominatifs, grand vélin d'Arches, vélin blanc de Lana é la forme, vélin du Marais filigrané, vélin sur Moulin de Larroque, vélin sur vergé de Montval, vérge de Hollande, vélin teinté, vélin de Mandeure, sur Auvergne Richard-de-Bas, sur Auvergne filigrané Hainteny, vélin Johannot, vélin Canson et Montgolfier i szereg innych. Wiele $z$ tych papierów posiadało specjalnie projektowane znaki wodne (filigrany) z pełnymi nazwami czy inicjałami odnośnych stowarzyszeń.

Do dzisiejszego dnia we francuskich papierniach są jeszcze w użyciu nie znormalizowane, tradycyjne formaty papieru, stąd trudno jest precyzyjnie określić format wydawanych publikacji, można jednak zaryzykować twierdzenie, że znakomita więlkszość francuskich druków bibliofilskich ukazywała się w formacie, który można określić jako in-quarto $\left(4^{\circ}\right)$, znacznie rzadziej jako „petit in-4”, sporadycznie zaś jako in-octavo $\left(8^{\circ}\right)$. 
Nakłady publikacji ksztaltowały się na różnym poziomie. Niektóre $z$ towarzystw drukowały tyle tylko egzemplarzy, ilu miały członków, inne do tej liczby dodawały jeszcze zwykle 25-30 egzemplarzy dla współpracowników, bądź dlo dyspozycji zarządu, jeszcze inne do podstawowego nakładu (zwykle na lepszym gatunkowo papierze) dodawaly dodruk kilkudziesięciu egzemplarzy do handlu księgarskiego. Przeglądając jednak bibliografię ${ }^{21}$ druków publikowanych przez poszczególne stowarzyszenia można stwierclzić, iż na ogół nakłady te wahały się w granicach od 104 do 200 egz. Niekiedy w kolofonie wydawnictwa figuruje zapis „Tirage limité” bez podania liczby egzemplarzy ${ }^{22}$, co jednak zdarza się incydentalnie.

Niektóre $z$ wymienionych wcześniej stowarzyszeń bibliofilskich nie publikowało własnych wydawnictw, lecz jak to czyniło na przykład La Société cles XX wchodziło "natomiast w układy $z$ poszczególnymi wydlawcami i zamawia u nich po 20 egzemplarzy, na specjalnym papierze, nowych wydawnictw, które uzna za interesujące. Egzemplarze te nie są zeszyte, i obok luźnej okładki wydawcy, posiadają specjalną okładkę ilustrowaną, dla każdego członka inną; najczęściej podpisane są przez autora i przez wydawcę"23. Do czasu II wojny członkowie stowarzyszenia otrzymali w ten sposób clwieście kilkadziesiąt publikacji.

\section{Czasopisma bibliofilskie}

Towarzystwa bibliofilskie, które licznie powstawały w XIX/XX w., jako jeden z głównych celów działalności (zwykle uwidoczniony w statucie stowarzyszenia) stawiały te $\dot{z}$ obowiązek wydawania czasopisma. Obok tych czasopism będących organem konkretnego towarzystwa, we Francji istniały bardzo liczne periodyki poświęcone miłośnikom książki, wydawane jednakże poza obrę̧em zrzeszeń bibliofilskich - przez wyclawców prywatnych (domy wydawnicze, księgarnie nakładowe).

Najstarszym we Francji pismem poświęconym bibliofilstwu, bibliotekarstwu i bibliografii był „Bulletin du Bibliophile et du Bibliothécaire”, miesięcznik, założony w Paryżu w 1834 r. Wśród jego twórców spotykamy tak głośne w dziejach książki nazwiska, jak: Joseph Techener ${ }^{24}$, Charles Nodier ${ }^{25}$, B. Pichon ${ }^{26}$, Pierre Lacroix ${ }^{27}$, Gabriel Peignot ${ }^{28}$ i Jacques Charles Brunet ${ }^{29}$. Oprócz zasadniczych artykułów z dziedziny szeroko pojętej bibliologii, czasopismo podawało stałe kroniki o ruchu wydlawniczym, mogące interesować kolelicjonerów, i tralktowało obszernie o zagadnieniach związanych $z$ historią książki. Prenumeratorzy otrzymywali bezpłatnie katalogi aukcyjne ${ }^{30}$.

Pierwszym $z$ francuskich czasopism fachowych, przeznaczonych wyłącznie dla miłośników i kolekcjonerów książek było „Le Bibliophile illustré” wydawane wspólnie przez firmy Trübner \& Co w Londynie i W. Jeffs, Librairie Etrangere de la Familie Royale. Pierwszy numer pisma ukazał się 15 sierpnia $1861 \mathrm{r}$. Pismo redagowali Jean Philippe Berjeau, Paul Lacroix, George Brunet, Johannes Willem Holtrop ${ }^{31}$. Zeszyty drukowano w formacie $25 \times 17,5 \mathrm{~cm}$, w objętości 16 stronic każdy. Poza rozprawami w czasopiśmie występowała stała rubryka Variétés (Rozmaitości), w której omawiano różne ciekawostki bibliofilskie. Pis- 
mo było bogato ilustrowane oryginalnymi drzeworytami. Nakład czasopisma wynosił 500 egz.

Następnym miesięcznikiem był publikowany w Paryżu od stycznia $1862 \mathrm{r}$. "Le Chasseur Bibliographe”, wydawany przez Societé de Bibliographes et de Bibliophiles. Każdy numer czasopisma liczył 32-36 stronic, na których pomieszczano 1-2 obszerne rozprawy, a clalszą część pisma zajmowały stałe rubryki, obejmujące miscellanea bibliograficzne i anegdotyczne, korespondencję, doniesienia $z$ aukcji książek i rękopisów, notatki $z$ cyklu rara et curiosa. Ta ostatnia rubryka to w zasadzie bibliografia adnotowana, obejmująca w każdym numerze 50 pozycji książkowych. Ponadto w niektórych numerach poszczególnych roczników zamieszczano wykazy francuskich bibliofilów ( $z$ podziałem na Paryż i departamenty) oraz stałą rubrykę cen uzyskiwanych na aukcjach Paryża i Rzymu. Materiału dopełniała bardzo bogata część sprawozdawczo-bibliograficzna (omówienia dawnych oraz nowych pozycji wydawniczych).

Jako kolejne pismo zaczęło wychodzić od 1864 r. "L'intermédiaire des Chercheurs et Curieux". W okresie międzywojennym był to dwutygodnik, w poręcznym formacie $8^{\circ}$, drukowany dwuszpaltowo, liczący przeciętnie 40 stronic tekstu. Głównymi współpracownikami pisma byli sami czytelnicy, przesyłający do redakcji pytania $z$ dziedziny historii literatury, bibliografii etc. Wydawnictwo to było nader cennym źródłem informacji dla wszystkich użytkowników związanych $z$ kulturą książki, w tym głównie bibliofilów: oddawało ogromne usługi przy kwerendach historyczno-literackich.

Cztery lata później pojawiło się pierwsze regionalne czasopismo bibliofilskie we Francji, jako "Publications de la Societé des Bibliophiles de Guyenne”. Wydawane było w Bordeaux od 1868 r. przez Société des Bibliophiles de Guyenne. Niskonakładowy periodyk drukowano w Impr. Taffard. Było to jedno z ładniejszych czasopism bibliofilskich $\mathrm{z}$ pięknymi szerokimi marginesami, o formacie $20,5 \times 13,5 \mathrm{~cm}$, tłoczone na znakomitej jakości papierze czerpanym, w ograniczonym do liczby członków nakładzie (każdy egzemplarz numerowany, imienny, $z$ drukowanym w maszynie nazwiskiem właściciela). W pierwszym tomie zamieszczono statut SdBdG oraz listę członków. Bardzo obszerne rozprawy, przekraczające niekiedy objętość 80 stronic tekstu dotyczyły głównie regionalnych i lokalnych zagadnień związanych z historią literatury. W 1932 r. pismo zmieniło tytuł na „Bulletin de la Société des Bibliophiles de Guyenne”i ukazywało się jako półrocznik. Zawierało głownie materiały i dokumenty do działalności Towarzystwa, ponadto wiadomości o bibliotekach, archiwach i ruchu wydawniczo-księgarskim w południowo-zachodniej Francji. Stałymi działami czasopisma są kronika stowarzyszenia oraz część bibliograficzno-recenzyjna. Pismo charakteryzowało się dość jednolitą formą, przemawiającą do czytelnika głównie pięknym rozmieszczeniem telsstu na kolumnie. Brak było na ogół ilustracji, niekiedy tylko pojawiał się oryginalny miedzioryt na odrębnej wkłarlce.

W 1890 r. zaczął wychodzić w Paryżu rocznik wyclawany przez Societaires de L'Academie des Beaux Livres pod nazwą ,Annales Littéraires. Publications collective des Bibliophiles contemporains". Wydawany na papierze czerpanym ze znakami wodnymi ABL (Academie des Beaux-Livres) oraz Société des Bibliophiles contemporains, w dużym formacie $26 \times 17 \mathrm{~cm}$ - prezentował się nader okazale. Karta przedtytułowa ozdobiona była winietką akwatintową $z$ ilustracją 
i numerem egz. nakładu. Karta tytułowa tłoczona drukiem dwubarwnym czarno-czerwonym oraz winietą śródtytułową akwatintową w kolorze sepii, przedstawiającą atrybuty bibliofilskie - stare księgi. W pierwszym roczniku występuje piękny miedzioryt kolorowany, przedstawiający portret Elżbiety królowej Rumunii (Carmen Sylva) - prezydenta honorowego Towarzystwa Bibliofilów oraz wiersz panegiryczny. Bardzo szeroki $5 \mathrm{~cm}$ margines, doskonały papier, staranny druk, kolumny tekstu ujęte w pięlkne ramki o motywach kwiatowych, winietki nadtytułowe i stylizowane inicjały oraz liczne ilustracje na odrębnych tablicach - stanowią o wytworności wydawnictwa, które jednak miało niezbyt długi zywot. Drukowane było w nakładzie $250 \mathrm{egz}$. (za 1891 r. - w nalkładzie 225 egz.).

"Revue Biblio-Iconographique" to kolejne czasopismo założone w $1897 \mathrm{r}$. w Paryżu. Pismo o formacie $24,5 \times 15,5 \mathrm{~cm}$ posiadało kartę tytułową dwubarwną, otoczoną stylową kwiatową bordiurą, piękne szerokie marginesy, a każdy artykuł rozpoczynał się ozdobnym inicjałem. Artykuły tu pomieszczane były niewielkiej objętości 3-5 stronicowe, a ważną częścią periodyku był wykaz aukcji bibliofilskich $z$ podaniem cen wylicytowanych.

Jednym $z$ najbardziej udanych edytorsko przedsięwzięć w zakresie wydawnictw ciągłych był wydawany w Paryzu przez Eduarda Pelletena ${ }^{32}$ "Almanach du Bibliophile". Jego pierwszy tom ukazał się za $1898 \mathrm{r}$. Było to luksusowe wydanie $z$ pięlknymi ilustracjami, znakomicie dobraną czcionką, o starannym, nawet perfekcyjnym tłoczeniu na świetnym gatunkowo papierze. Wydawnictwo miało format $19 \times 13,5 \mathrm{~cm}$, okładkę $z$ grubego papieru czerpanego, druk dwubarwny czarno-czerwony. Nakład almanachu był stosunkowo wysoki i wynosił 1200 egzemplarzy, w tym $100 \mathrm{egz}$. na papierze chińskim (50 z oryginalnymi ilustracjami na oddzielnych wkładkach i $50 \mathrm{z}$ ilustracjami w tekście). Ilustrował owo wydawnictwo 28 rycinami Bellery-Desfontaines, a rytowal Froment.

Kolejne roczniki A/manachu ukazywały się w niezmienionej co do struktury i równie wytwornej formie jeszcze zaledwie kilka lat, do $1901 \mathrm{r}$. włącznie. Wahał się jedynie nieco nakład, który w 1899 i 1900 r. zmniejszono do 1000 egz., w 1901 r. - do 900 egz. Wśród autorów piszących na łamach Almanach du bibliophile, spotykamy nazwiska najznakomitszych ówczesnych francuskich bibliofilów i znawców problematyki książki zabytkowej oraz literatów czy ludzi nauki, członków Akademii Francuskiej takich, jak Anatole France, J.K. Huysmans $\mathrm{i}$ inni, oraz takich artystów grafików, jak Eugéne Grasset, D. Vierge, czy też Th. Steinlein, Ch. Guérin i drzeworytników, jak F. Pellison, C. Bellenger i inni.

Założony w 1911 r. „Annuaire de la Curiosité, des Beaux Arts et de la Bibliophilie" to rocznik o polkaźnej objętości (zwykle powyżej 600 stronic), będący w zasadzie informatorem zawierającym adresy zbieraczy francuskich ( $z$ podzialem na Paryż i poszczególne departamenty) oraz zagranicznych, wykaz antykwariatów księgarskich a także obszerną część komercyjno-reklamową, bogato ilustrowaną, w tym wykazy rzadkich, cennych i poszukiwanych książek i rękopisów wystawianych na aukcjach, głównie w Hôtel Drouot. W poszczególnych rocznilkach są też prezentowane wybitne kolekcje, bądź rozprawy dotyczące zbieractwa ${ }^{33}$. 
Wśród bardzo licznych francuskich czasopism bibliofilskich wyróżniał się, założony w 1925 r. w Paryżu, kwartalnik milośników książki współczesnej pn. „Plaisir de Bibliophile”. Ukazywał się w dwóch wersjach, o zróżnicowanej cenie na papierze zwykłym oraz na welinie (ta wersja zaledwie w 60 numerowanych egz. ${ }^{34}$ ). Niewielki, poręczny format $19 x 14 \mathrm{~cm}$. kryje niezwykłe bogactwo formy i treści. Olkładka czasopisma barwna, bardzo ozdobna, za którą następuje część reklamowa (w pierwszym roczniku na papierze koloru niebieskiego, w kolejnych na papierze żółtym) zawierająca reklamy wyclawców, drukarzy, introligatorów, księgarzy itc. Zrąb główny czasopisma na białym, doskonałej jakości papierze zawiera dużą liczbę ilustracji bądź w tekście, bądź ná oddzielnych wkładkach. Każdy artykuł rozpoczyna się pięknym, ozdobnym inicjałem. Pismo zawiera też część sprawozdawczą, na którą składają się relacje $z$ wystaw, sprawozdania $z$ aukcji i licytacji bibliofilskich oraz omówienia książek w formie bibliografii adnotowanej. „Plaisir de Bibliophile” dużo miejsca poświęcał informacjom o działalności francuskich towarzystw bibliofilskich (m.in. omówiono takie stowarzyszenia, jak: Les Cent Bibliophiles, Le Livre Contemporain, Le Livre d'Art, Les Médecins Bibliophiles, Les Bibliophiles du Palais i inne).

"Le Bibliophile, revue artistique et documentaire du livre ancien et moderne", założony w Paryżu w 1931 r., wychodził pięć razy na rok. Wydawany w dużym nakładzie 1000 egz. numerowanych był dosyć kosztowny (45 fr. zeszyt), gdyż pismo drukowano na specjalnym papierze, fabrykowanym $z$ papirusu. Treść pisma była różnorodna i obejmowała zarówno artykuły i rozprawy naukowe o technice książki (druku, ilustracjach, oprawach), jak też informacje o bibliotekach publicznych i księgozbiorach prywatnych, o nowych publikacjach bibliolilskich, doniesienia o aukcjach i licytacjach, a także lżejszą w treści kronikę anegclotyczną o rzadkich starych książkach. Zeszyty tego cennego czasopisma były bogato ilustrowane pięknymi reprodukcjami, do poszczególnych numerów co pewien czas dołączano w postaci premii oryginalną grafikę (głównie miedzioryty).

Do wymienionych powyżej czasopism dorzucić jeszcze można kilka tytułów, takich jak np. „Le Bouquiniste français” (pismo założone w 1919 r., specjalizujące się w publikowaniu wykazów ksiązek rzadkich i poszukiwanych), „Gazette de l'Hotel Drouot" (wychodząca od 1892 r., publikująca kroniki i sprawozdania licytacji antykwarycznych francuskich i zagranicznych), mający podobny charakter "Moniteur de Ventes" (założone w 1832 r. najważniejsze pismo informacyjne o wszystkich licytacjach bibliofilskich), czy specjalistyczne, lecz dla bibliofilów barclzo interesujące czasopisma, jak: "L'EX-Libris, revue internationale" (założone 1929, bardzo ozdobnie wydawane, $z$ kilkudziesięciu ilustracjami w tekście i na oddzielnych tablicach, zajmowało się znakiem książkowym w formie malej grafiki artystycznej i supereklibrisami, głównie o motywach heraldycznych), lub „La Reliure” (organ Związku Introligatorów, założony w 1891 r., publikował obficie reprodukcje opraw artystycznych).

Jako ciekawostkę możemy podać, iż w wielu wydawnictwach zrzeszonego francuskiego ruchu bibliofilskiego napotykamy dość liczne polonika, czy to w specjalistycznych periodykach, czy też samoistnych publikacjach bibliofilskich. W czasopiśmie „Le Bibliophile illustré” $z 1861 \mathrm{r}$. jest ciekawy artykuł P. L. Jacob'a w formie korespondencji do A. M. Berjeau, wydawcy pisma, o bib- 
liotece cesarskiej w Petersburgu i o Józefie Załuskim - jego pracach bibliograficznych oraz bibliotece w Warszawie ${ }^{35}$. $Z$ kolei w "Annuaire de la Curiosité" mamy istne curiosum: w rubryce zawierającej nazwiska kolelicjonerów zagranicznych - ze zbieraczy polskich spotykamy tylko jedno nazwisko - niejakiego pana Józefa Litwina, zamieszkałego w Łodzi przy ul. Piotrkowskiej 108, kolekcjonera starych i nowych papierów wartościowych: banknotów z $1792 \mathrm{r}$. oraz lokalnych $z$ lat 1914-1920. Jedno $z$ francuskich towarzystw bibliofilskich wydało też jako swoją publikację dzieło naszego sławnego rodaka Jana Potockiego Manuscrit trouvé a Saragosse.

Dziś ruch bibliofilski we Francji jest równie żywy, jak dawniej, a stowarzyszenia mające długą tradycję oraz te nowopowstałe, kontynuują piękne osiągnięcia francuskich miłośników książki.

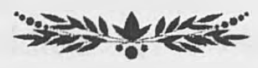

Przypisy:

${ }^{1}$ Encyklopedia wiedzy o ksiązce, Wroclaw 1971, szp. 735.

${ }^{2}$ S. Dahl, Dzieje ksiaziki, Wrocław 1965, s. 300.

${ }^{3}$ Wprawdzie początków bibliografii bibliofilskiej dopatrywać się możemy już w pracy

J. B. L. Osmonta, Dictionnaire typographique, historique et critique des livres rares..., t. 1-2, Paris 1768 , bardziej jednak ceniona byla praca wydana równolegle $z$ poprzednią, autorstwa Guillaume François Debure'a młodszego pt. Bibliographie instructive..., Paris 1763-1768. Dzieło Debura dopełniali Louis Jean Gaignat w 1769 r. i Née de la Rochelle w $1782 \mathrm{r}$.

${ }^{4}$ S. Dahl, op. cit., s. 301.

${ }^{5}$ Listes des Sociétés de Bibliophiles, w: Almanach du Bibliophile pour année 1898, Paris, s. 101-258.

${ }^{6}$ K.[azimierz] W.[oźnicki], Ważniejsze towarzystwa bibliofilów we Francji, „Bibliofil Polski", 1933, nr 1, s. 36-39.

${ }^{7}$ Gygès: Les sociétés de bibliophiles - Les Cent Bibliophiles, „Plaisir de Bibliophile”, R. 1, 1925, nr 1, s. 39-45; nr 2, s. 89-95.

${ }^{8}$ Henri Béraldi (1849-1931) kolekcjonował ilustracje i książki o dużej wartości artystycznej, interesował się pięknymi oprawami. Popieral usilnie działalność typograficzną Eduarda Pelletana, był autorem znanej i cenionej pracy: Bibliothèque d'un bibliophile (Lille 1885).

${ }^{9}$ Listes des Sociétés de Bibliophiles [in:] Almanach du Bibliophile pour année 1898, Paris, s. 101-258.

${ }^{10}$ Oferowany byl niedawno w katalogu Librairie du Manoir de Pron w cenie $350 €$.

${ }^{11}$ K. Woźnicki, Bibliofilstwo powojenne we Francji, „Bibliofil Polski”, 1933, nr 1, s. 29.

${ }^{12}$ „Bibliofil Polski”, 1933, nr 1, s. 30.

${ }^{13}$ Ibidem.

${ }^{14}$ Librairie des Bibliophiles Parisiens opublikowala m.in. poetycki dramat Oscara Wilde’a pt. Salome... (1920) w nakładzie 285 egz. 
${ }^{15}$ Status societe des bibiophiles de Guyenne [in: „Publicationes de la societé”], t. 1, 1868, p. IX-XI.

${ }^{16}$ Jest to książka Paula Claudel'a La Rose et le Chèvrefeuille, $z$ ilustracjami Othona Coubine'a, wydana sine loco.

${ }^{17}$ W 1945 r. wydalo sine loco utwór Alfreda de Musset On ne badine pas avec I'Amour, z akwafor tami Jeana Trainiera, w nakładzie $110 \mathrm{egz}$.

${ }^{18}$ Grupowało m.in. czlonków z Amsterdamu, Bazylei, Berlina, Bordeaux, Dijon, Grodna, Helsinek, Kowna, Lipska, Londynu, Madrytu, New Yorku, Oksfordu, Pragi, Strasburga i Warszawy.

${ }^{19}$ Jedyna znana mi publikacja tego Towarzystwa, ukazala się w 1926 r. Jest to utwór Alfreda Jarry'ego Les Silénes..., $z$ frontispisem grawerowanym w akwaforcie przez Galanis'a. Jako miejsce wydania figuruje Papeete, książka faktycznie wydana i drukowana była w Paryżu, nakład 104 egz.

${ }^{20}$ Są wśród nich m.in. Maurice Barres La Colline Inspirée (1941), Charles Baudelaire Le Spleen de Paris (1941), Edmond Pillon Les Jolies Vallées de l'Ile de France (1944), Jean Racine Phédre (1942), Virgile Les Bucoliques (1943).

${ }^{21}$ Do powyższych celów zgromadzono spis bibliograficzny publikacji francuskich towarzystw bibliofilskich za lata 1875-1986, obejmujący blisko tysiąc pozycji książkowych.

${ }^{22}$ Tak np. jest w opublikowanej przez Les Bibliophiles Alesiens w 1942 r. książce Paula Claudela La Rose et le Chevrefenille.

${ }^{23} \mathrm{~K}$. Woźnicki, Ważniejsze towarzystwa..., s. 37.

${ }^{24}$ Znakomity antykwariusz z Lyonu, którego działałność kontynuowal syn Léon. Na aukcjach u Techenerów sprzedawano rzadkie druki, m.in. z kolekcji Groliera.

${ }^{25}$ Charles Nodier (1780-1844), bibliotekarz Biblioteki Arsenału w Paryżu, bibliograf i bibliofil posiadający duży księgozbiór z nader rzadkimi drukami w cennych oprawach. (zob. M. Henry-Rosier: La Vie de Charles Nodier, Paris 1931).

${ }^{26} \mathrm{~B}$. Pichon, znany wydawca, dbal niezwykle o estetykę (ilustracje i staranny druk) publikowanych książek.

${ }^{27}$ Jako pierwszy dal zarys psychofizjologii bibliofilstwa i bibliomanii.

${ }^{28}$ Etienne Gabriel Peignot (1767-1849) bibliotekarz, teoretyk bibliografii i autor znanych i cenionych bibliografii bibliofilskich.

${ }^{29}$ Jacques Charles Brunet (1780-1867, księgarz, bibliofil, bibliograf, twórca najgłośniejszej bibliografii bibliofilskiej Manuel du libraire et de l'annateur des livres, Paris 1810 (zob. C. Olschki, Témoignages contemporains sur la vie et l'oeuvre de Jacques Charles Brunet. - Paris 1962).

${ }^{30}$ Czasopismo ukazywało się do II wojny światowej. Wznowione następnie, jako Nouvelle série, od 1948 r. wyd. przez Librairie Giraud-Badin, następnie we wspólpracy z Bibliothéque Nationale, Bibliothéque de l'Arsenal oraz Société des Bibliophiles François, na przełomie lat 1969/1970 zmieniło tytuł na „Bulletin du Bibliophile”.

${ }^{31}$ Holtrop byl znakomitym znawcą inkunabułów, autorem świetnej pracy pt. Catalogus librorum saeculo XV impressorum quotquot in Bibliotheca Regia Hagana asservantur. Hagae-Comitum, Nijhoff, 1856. XXXIII, 592 p. Pars I - Libri in Belgio impressi. 651 p. Pars II - Libri extra Belgium impressi. 923 p.

${ }^{32}$ Edouard Pelletan (1854-1912) drukarz i wydawca czynił wysiłki w kierunku podniesienia artystycznego poziomu $i$ harmonijnego powiązania układu typograficznego 
z ilustracją książki. W 1896 r. opublikował Lettres atxx bibliophiles, gdzie wysunąl postulat stosowania tylko drzeworytu, jedynej techniki graficznej wiążącej się z czcionką.

${ }^{33}$ Np. na s. 68-75 Maurice Escoffier przedstawia opis i ilustracje superekslibrisów kardynała Mazarina, księcia de Richelieu, Mme Pompadour, Ludwika XV, kardynała de Richelieu, Ludwika XIV i innych.

${ }^{34}$ Kosztowała $60 \mathrm{~F}$ luls $3,50 \$$ czyli 17 zł 50 gr: polskich.

${ }^{35}$ „Le Bil)liophile illustré", 1861, nr 5, s. 77-80. 